\title{
George Radin on Bishop Dr. Nicholai Velimirovich and the Serbian Orthodox Church in America
}

\author{
Nemanja Andrijašević \\ Orthodox Theological Faculty at the University of Belgrade \\ nemanja.andrijasevic@gmail.com \\ ORCiD https://orcid.org/0000-0002-4598-5304
}

\begin{abstract}
George Radin (Đorde Radin, 1896-1981) was one of the numerous Serbian emigrants in the USA in the period right before WW2. He studied at the most eminent American Universities and had become an attorney, then a lawyer and finally an expert in international law. He managed to achieve great success and expertise in the field of American foreign politics and diplomacy.

In the period between the two World Wars, he met Bishop Dr. Nicholai Velimirovich who made a strong impression on him. He was the Bishop's guide across the USA during his two visits there: in 1920 and in 1927. During his first visit to the continent, the Bishop had organized the life of the Serbian Orthodox Church (SOC), considering that at the time SOC didn't have its residing bishop there.

Radin was, according to his own testimony, one of the organizers of the Bishop's arrival to America at the beginning of 1946. He had been of the opinion that this significant Bishop should live in one of the Protestant Churches and hold lectures at the Universities, thus serving SOC and its members. In other words, it was his conviction that the Bishop should have organized the church life in the same way he did in his previous two visits to the USA. However, the situation between the two World Wars was far more complicated. The Serbian Church had by that time appointed its ruling bishop in America and Canada - Dionisiye Milivoyevich (Dionisije Milivojević, 18981979), who parted ways with Bishop Nicholai soon after his arrival to the USA. Immense damage had been done to the SOC by the utter lack of cooperation between these two bishops. Bishop Nicholai found a "Solomon's solution" for
\end{abstract}


this by deciding to live and work in Saint Tikhon's Orthodox Monastery in South Canaan, Pennsylvania. It was in this holy place that he reposed in 1956.

Until the end of his life, Radin was of the opinion that a fundamental mistake had been made by the secession of the opportunity that through abiding in the Protestant communities Bishop Nicholai might do more for the SOC and the Serbs, especially through his acquaintances and contacts with the representatives of other Christian confessions, primarily Protestants. He mentioned this in his correspondence with Slijepchevich (Đoko Slijepčević, 1908-1993). Also, Radin made all the efforts in his power to help overcome the current schism in the SOC. He wrote about his opinions, ideas and steps taken in that direction to the bishops of the Serbian Church, as well as the Patriarch German Djorich himself. Even though the Patriarch of the SOC also made efforts to help overcome the schism, at one point he told Radin that this unfortunate and extremely difficult issue is an internal matter of the SOC, and thus should be dealt with internally. In the appendix of this work, there are excerpts from the letters found in the Radin - Slijepchevich correspondence. They illustrate the enormous mutual trust and respect that these two acquaintances had for each other, having met by the mediation of Bishop Nicholai. The excerpts also present the opinions of the respectful lawyer and law expert - Radin who, in his own way, tried to contribute to the benefit of the SOC. They also convey his judgment on the importance of Bishop Nicholai as well as his discernment about the missed opportunity that the above mentioned bishop should have been presented with in order to contribute more to the SOC, its faithful people and all the Serbs in general - on the American continent, as well as in the whole world. It is clear that he remained hindered in that respect - among other factors - by the will of Bishop Dionisiye. Only a few years after the death of Bishop Nicholai, the most complicated problem of the SOC in diaspora unraveled - the schism. Radin directed all his attention and efforts towards the solution of this problem, in the ways he considered to be the most acceptable. In all this he had agreement with and support of Slijepchevich, with whom he had researched the best ways of achieving reconciliation. Fragments of his letters imply that the majority of his emigrant life he devoted to taking care of Bishop Nicholai, as well as fighting against schism and finding the possibilities of its overcoming.

Key words: Bishop Dr. Nicholai Velimirovich, Serbian Patriarch German Djorich, George Radin, Prof. Dr. Djoko Slijepchevich, Bishop Dionisiye Milivoyevich. 


\section{Ђорђе Радин о Владици др Николају Велимировићу и Српској Православној Цркви у Америци}

Немања Андријашевић

Православни богословски факултет, Универзитет у Београду

Апстракт: Владика др Николај Велимировић, за кога је руски теолог и свештеник проф. др Александар Шмеман у свом Дневнику 1976. записао да је „најистакнутији православни епископ двадесетога столећа", провео је последњу деценију свог живота и служења у Америци. Један од његових пријатеља и сарадника био је и српски исељеник адвокат Ђорђе Радин. Он је у дописивању са историчарем проф. др Ђоком Слијепчевићем поменуо поједине, мало познате, сегменте из живота Епископа Николаја у послератном периоду. Садржај рада чине непознати и необјављени фрагменти неколико Радинових и Слијепчевићевих дописа, као и једно писмо Патријарха српског Германа Ђорића.

Кључне речи: Владика др Николај Велимировић, Патријарх српски Герман Ђорић, Ђорђе Радин, проф. др Ђоко Слијепчевић, Владика Дионисије Миливојевић.

\section{Увод}

Историчар и теолог проф. др Ђоко Слијепчевић (19081993) имао је две животне фазе. У првој је стварао у отаџбини, до 1944. године, док је у другој радио у изгнанству, као политички емигрант. Дописивао се са разним личностима на многим меридијанима, у вези са бројним питањима. У Слијепчевићевој сачуваној преписци са Ђорђем Радином (George Radin, 1896-1981)² из Америке

\footnotetext{
${ }^{1}$ Преписка се налази у власништву аутора рада.
} 
пронађена су Радинова помињања архијереја др Николаја Велимировића (1880-1956) и битних догађаја при Српској Православној Цркви (СПЦ) у Сједињеним Америчким Државама (САД).

Недостатак обимне и критички написане биографије шездесет и пет година после смрти неоспорно познатог и признатог архијереја, о коме се проф. др Александар Шмеман изразио позитивно, и то у суперлативу, ${ }^{2}$ представља ружну слику о изостанку правилног, објективног и поштеног изучавања и вредновања личности и рада Владике Николаја Велимировића. Овај рад управо има за циљ да се кроз Радинова сведочанства поједини моменти мало боље осветле и прикажу, премда би требало имати критичку дистанцу према његовим тврдњама и сећањима (па и изневереним надањима) која су записана неколико година и деценија након што су се одиграла.

\section{Ко је био Ђорђе Радин?}

Ђорђе Радин рођен је 29. јануара 1896. у Војводини, тадашњој Аустро-Угарској. Отац му се звао Добривоје, а мати Персида. Прва сећања из детињства била су му везана за мајку: „њено плакање на разбоју (где нам је ткала гаће и кошуље - родила је шест синова) кроз певање песме о Косову“.3 Завршио је четири разреда „у парохијалној шко-

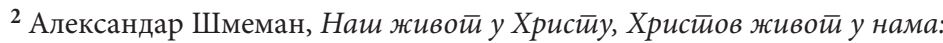

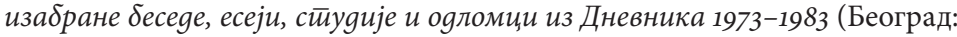
Мисионарска школа при Храму Светог Александра Невског, 2007), 564.

${ }^{3}$ Радиново писмо Слијепчевићу од 6. фебруара 1970. Истакао је истом адресату 2. новембра 1973. и: „Још увек ми је пред очима и у души моја мати, како седи на столици испред разбоја. Са народним песмама кроз плакање ткала је платно за своја шест синова да облаче, од којих сам најмлађи и једини још у животу. Тај доживљај у почетку мог живота (једва ми је било нешта више од 3 године) остао је и живи у мојој души куд и камо више него све историје које сам учио и читао целог живота.“
} 
ли у Банату, са главним - ваљда и јединим - предметима веронауке и црквене песме на старословенском језику“. Иселио се 1912. у Америку, у којој се школовао при Колеџу Колумбија и тамошњој Правној школи (Columbia College and Columbia Law School). Проф. др Михаило Пупин изабрао га је с јесени 1918. да на Универзитету Колумбија (Columbia University) заинтересованим студентима предаје српски језик. ${ }^{5}$ Међународно право усавршавао је у Њујорку, Вашингтону, Цириху и Београду, због чега се с правом сматра да је био његов изузетан познавалац. Био је један од секретара Америчко-југословенског друштва, основаног 1923. године. 6 У адвокатури је радио од 1925, а каријеру је започео у Адвокатској канцеларији Хорнблауер, Милер и Гарисон (Hornblower, Muller \& Garrison). Био је члан адвокатске коморе у Њујорку и Вашингтону.

\footnotetext{
4 Радиново писмо Слијепчевићу од 23. марта 1966.

5 Поменуо је ово у писму Слијепчевићу 17. маја 1966. Детаљније му је о томе нагласио 2. новембра 1973. следеће: „Овде је тешко наћи стварно погодну особу за вођење тог курса. То се показало и одмах ујесен, када се је потписало примирје у Првом Светском Рату. Пупин је предложио Колумбији Универзитету мене, без мог знања, а то је имао бити први курс српско-хрватског језика у једном свеучилишту у Америци. Када ми је ту вест усмено саопштио, толико сам се уплашио да сам му инстиктивно одговорио: 'То никако несмем прихватити. Па ја сам једва freshman y Kolumbia College-y. Цео свет би ми се уочи смејаo'. Професор је одговорио: 'Синоћ се је одржала седница Савета на универзитету. Решено је да се одмах оснују класе језика свих Савезничких земаља. Сви присутни су гледали у мене због огромног херојства Срба-великомученика у овом рату. Морао сам без икаквог оклевања гласати за оснивање класе за учење српског језика. Предложио сам Вас за првог наставника, што је једногласно усвојено - пошто сам рекао да постоје два Србина на Универзитету, један овде рођен који незна српски, и Ви који знате српски језик. Одлука је већ код штампара, а професор Prince ће Вас известити у којој сали и време када Ваша класа почиње. А Ви, избаците одмах страх. Знајте то, да ниједан ђак у тој класи незна ни близу српски језик колико га Ви познајете.“

6 Председник поменутог удружења био је Хамилтон Фиш Армстронг (Hamilton Fish Armstrong), пријатељ архијереја Николаја Велимировића и носилац неколико српских одликовања.
} 
Оженио се Катарином Хаџи Поповић, ${ }^{7}$ ћерком имућног судије, а Света тајна брака савршена је у храму Светог Марка у Београду 1928. године. Од 1930. до 1941. живео је и радио у Београду. ${ }^{8}$ Током Другог светског рата био је посебни представник краља Петра II Карађорђевића у Вашингтону. ${ }^{9}$ Имао је ћерку Виду (Vida Stringer, poђена 1933) и унуку Гоју (Geoya). Са историчарем Чарлсом Бердом (Charles A. Beard) био је коаутор дела The Balkan Pivot: Yugoslavia. Написао је и књигу Post-War Economic Reconstruction: A Practical Plan for the Balkans. Организовао је и самостално водио обиман подухват обештећења логораша српске националности који су Други светски рат провели као принудни радници интернирани у Немачкој. ${ }^{10}$ И поред преданог ангажмана за преко 10.000

7 Тетка његове супруге била је чувена Катарина Јовановић Катица (1869-1954) из Цириха, велики задужбинар и оснивач значајне српске библиотеке у поменутом граду. Превела је Горски вијенаи, и Лучу микрокозму на немачки језик.

${ }^{8}$ Овај период обавијен је извесном мистеријом. Повремено се у штампаним гласилима у Србији појављују записи и тврдње о Радиновом закулисном учешћу у крупним политичким догађајима који су претходили уласку Југославије у Други светски рат. Ипак, у прегледаним архивама није пронађен никакав податак о томе. Поменуте претпоставке за сада није могуће проверити и упоредити у доступној архивској грађи. Занимљиво је да је Радин избегавао да коментарише тај временски период у својим писмима упућеним Слијепчевићу.

9 У писму Владици Фирмилијану 7. јула 1966. истакао је промашај који је настао као плод „зависти и негодовања“ Посланства Краљевине Југославије у Америци, којем се Радин као представник југословенске владе из Лондона, у чије име је послат у мисију у САД, јавио. Он је Посланству указао на важну чињеницу да ће организовати један саветодавни одбор, који ће бити састављен од „америчких јавних радника са угледом и ван Америке“. Ипак, Посланство је ово одбило као непотребно и сувишно, због чега је Радин проценио: „На овај начин, у критичним данима по српски народ изгубили смо пријатељство утицајних људи у најмоћнијој земљи - и како се све то завршило, историја говори а Срби плачу.“

10 У писму потпуковнику Угљеши Михајловићу, председнику Америчког удружења ратника из Чикага, Радин је 3о. октобра 1967. поменуо да су га „молили и Краљ Петар, б.[ивши] председник владе професор Слободан 
оштећених које је заступао - а који су били искоришћени као неисплаћена радна снага - током процеса у трајању од две деценије, ${ }^{11}$ у томе није имао успеха. Такође, предано се заузео и за прихват Срба који су емигрирали у САД после $1945 .^{12}$

Становао је три деценије у престижном хотелу „Вардман парк“ („Wardman Park“) у Вашингтону. ${ }^{13}$ Био је оснивач и први председник Међународног фонда за развој (International Development Foundation). ${ }^{14}$

Дуги низ година предузимао је кораке да се дође до прекида раскола и измирења при СПЦ у Америци. Тим поводом контактирао је с појединим владикама ове верске заједнице и у САД и у Југославији, ${ }^{15}$ чак и с Патријар-

Јовановић и наш Епископ Николај [Велимировић] да Вас заступам о овој Вашој толико праведној ствари“.

${ }^{11}$ Слијепчевићу је написао 10. марта 1971: „Међутим, у најновије време принућен сам да пустим другим Србима помагање толико важне потребе Срба расејаних по свету. Заступајући, са финансирањем, од 1947 г. наовамо речених десетак хиљада Срба-мученика (не тражећи и не примајући ни једну парицу ни од кога у свету за тај толико обилан рад, са посетама у Bonnu првих неких 18 година по три па и четири пута годишње), исцрпило ме је финансијски толико да сам морао донети одлуку да сада и даље финансирам вођење тог посла и те историске одговорности - а да другим Србима препустим остало. [...] За сада ту трошкови нису нарочити, али стално наилазе. Ова штампања хиљаде летака ради растурања по свету чланка из VOICE OF HUMAN RIGHTS, нико други нема да исплати сем мене. Нити ће се исплата тражити ма од кога другог.“

${ }^{12}$ Од 1947. имао је задужење Савета протестантских цркава Америке (Church World Service) да прима и утиче на смештање бивших ратних заробљеника Срба, „који нису нипошто хтели да се врате својим домовима у ропству атеиста којима су њини ратни савезници предали Југославију“.

${ }^{13}$ У то време су се у том хотелу одржавале годишње скупштине Међународне банке и Међународног монетарног фонда.

${ }^{14}$ Ово је и у данашњем времену веома важна, призната и утицајна међународна институција.

15 У писму Владици жичком др Василију Костићу 4. марта 1967. написао је: „Ваше преосвештенство, Радујем се што ми се поново указује прилика да пишем епископу славног Манастира Жиче где сам пре рата проводио многе срећне часове у друштву Вашег претходника, Епископа 
хом српским Германом Ђорићем. ${ }^{16}$ Слијепчевић је о Радину Владици западноевропском и аустралијском Лаврентију Трифуновићу 27. маја 1970. записао: „... адвокат из Вашингтона, који је велики пријатељ наше цркве и народа, Србин по рођењу, одавно амерички грађанин, ученик пок. Михаила Пупина и велики пријатељ и поштовалац пок. владике Николаја. [...] Подвлачим, да је г. Радин човек веома утицајан у Вашингтону, нарочито у Мин. спољних послова и у Конгресу. Знам, исто тако, да има добре везе са америчком Англиканском црквом.“ Радин је умро 4. јануара 1981. у старачком дому (Colonial Villa Nursing Home).

Николаја. Дај Боже да ми се такво задовољство поново укаже у недалекој будућности са Вама.“ Такође, у писму неименованом владици, највероватније поменутом Василију Костићу, 4. априла 1967. поменуо је и: „Јао, Јао - колико смо пок. Пупин, пок. Николај и ја радили да упознамо свет са Косовском Традицијом српског народа!“ После овог текста, откуцаног на машини, Радин је руком дописао: „Николај ми је лепо говорио о проти [Алекси] Тодоровићу.“ Ово је поновио и у писму Слијепчевићу 30. августа 1969. године, споменувши свештеника Алексу на следећи начин: „Молим Вас поздравите га топло. Николај је имао врло добро мишљење о њему. Зато је и моме срцу близак.“

16 Патријарху Герману слао је писма најчешће преко некога ко је путовао у Србију. Отац Алекса Тодоровић обавестио је Слијепчевића 23. марта 1967. да је поглавар СПЦ добио Радиново писмо и да је упознат са тиме да постоји још један важан допис, који се тренутно налази у Слијепчевићевим рукама. Прота Алекса цитирао је патријархово писмо: „Сазнајемо да Др. Ђ. Сл. има интересантно писмо од Ђ. Р. из САД. Сам Ђ. Р. писао је једном нашем сабрату о томе и упутио га да посети Ђ. Сл. да би сазнао садржину. Саветовали смо се и закључили да је много једноставније и јевтиније да нам се достави препис односно сиже садржине тога писма, управо његов циљ па кад видимо да је засновано на реалним основама и да има смисла да се нешто ради онда би се тек могло о свему даљем разговарати. Ово пишем зато што ми не престајемо бринути и тражити пута и начина да повратимо изгубљено стадо. Надамо се да ће нам у томе Бог и Свети Сава помоћи...“ 


\section{О преписци Радин-Слијепчевић}

Пронађена писма у сачуваној преписци проф. Ђока Слијепчевића и адвоката Ђорђа Радина, из којих су реконструисани пружени подаци у раду, настала су између 1951. и 1977. године. Поједина су исписана руком, док је већи део настао на машини за куцање. Делови текстова седам одабраних дописа пренесени су изворно, у прилогу рада. Ово је урађено зато што није било дописа у којима је помињана једна тема, већ су поједини моменти везани за личност Владике Николаја или одређене важне догађаје при СПЦ у Америци поменути успутно, без ширег осврта. Фрагменти писама корисни су за разумевање околности у којима је протицало првих неколико година живота и рада Епископа Николаја у САД, као и за сагледавање слике о верском животу Срба у емиграцији у другој половини 2о. века.

Преписка није сачувана у потпуности, што се закључује из појединих писама у којима Радин или Слијепчевић помињу да одговарају на добијени допис, али он се не налази у Слијепчевићевој архиви. Дописивања из педесетих година су ређа, односно обухватају неколико писама, она из шездесетих су најобимнија, док се из седамдесетих полако проређују.

Управо је архијереј Николај упутио Радина да упозна Слијепчевића и обавезао га да му помогне, уколико буде потребе за тим. ${ }^{17}$ После почетног усменог сусрета 1951. године, ${ }^{18}$ највероватније у Швајцарској у којој је Слијепчевић тада живео, уследила је вишегодишња преписка између њих. Било је и још неколико (кратких) виђања, која су поменута у писмима. Слијепчевић му је био захвалан због

\footnotetext{
17 У Радиновом писму Слијепчевићу 28. маја 1966. поменуто је: „Велики дух нашег Николаја вероватно је осећао пре толиких година да ће наићи време када ћете моћи бити од велике помоћи за добро Срба и њине велике традиције - па ми је зато саветовао да будем у тесној вези са Вама.“

18 Ово се закључује из Слијепчевићевог писма Радину од 29. маја 1951.
} 
заузимања и интервенисања у вези са тешкоћама путовања у САД, односно проблемима који су сваки пут искрсавали приликом потраживања туристичке визе за одлазак у Америку, с обзиром на то да је поменута држава поседовала информације о Слијепчевићевим денунцијацијама окупатору у Југославији током Другог светског рата. ${ }^{19}$

Једна од важних тема било је превођење Слијепчевићеве двотомне Истиорије Срйске Православне Цркве на енглески језик. ${ }^{20}$ И поред вишегодишњег договарања о томе, ово дело није било објављено на енглеском језику. Садржаји бројних страница односе се и на Радиново покретање Српске истраживачке фондације (Serbian Research Foundation) при цењеном Америчком универзитету у Вашингтону (American University), за шта је тражио и добио Слијепчевићеву подршку, као и бројне савете и упуте. Стварање ове институције требало је да послужи изучавању српске историје и културног доприноса. Иако је очекивао веће учешће Ђока Слијепчевића у том подухвату, до тога није дошло. Највероватније је Радин све то оформио пред крај периода у коме је био на врхунцу снаге, а после му није пошло за руком да остане при својој првобитној замисли о важности Слијепчевићевог активног учешћа при поменутој научној установи.

19 У писму Радивоју Бијелићу из Америке, рођаку протојереја-ставрофора проф. др Стевана Димитријевића, 11. октобра 1979. Слијепчевић је записао: „Велика Вам хвала на вестима о Радину. Врло ми је жао да је он у таквом стању. Он је мени био пријатељ у неким важним моментима око скидања наслага денунцијација против мене у тој земљи. Мене је њему био ставио 'у аманет’ покојни владика Николај и он се тога држао.“

20 У писму Слијепчевићу Радин је написао руком 1. августа 1969: „Што се тиче превода, изненадио ме је Американац Richard Oldrich (позната Кућа у Њујорку у којој је некада ђак Пупин поучавао једног дечка, деду Richarda, да положи испите). Не знам како је дошло до тога да Richard студира две године на Београдском Универзитету. Ниједан Американац до данас није разговарао српски са толиком лакоћом као што је он говорио са мном. Кад се врати у Вашингтон после ферије, питаћу га да ли је вољан да преведе ово Ваше дело.“ 
Када је у питању најкомплекснији проблем СПЦ у дијаспори у другој половини 20. века - раскол у САД, Слијепчевић и Радин саветовали су се и развијали стратегију, са циљем да се дође до превазилажења расцепа и измирења. Из њихових писама стиче се утисак да су били уравнотежени и вољни да посредују у томе да се болна тема реши. Приметно је и поверење које је владало између њих, па су тако један другом достављали копије писама упућене важним личностима. Слијепчевић је био посредник да поједини поверљиви Радинови дописи или обавештења дођу до неких архијереја СПЦ, па чак и самог поглавара. Занимљиво је да је Патријарх Герман једног момента одлучио да приватно одговори Радину. То писмо је у потпуности унето у прилог рада. Из њега се закључује да је патријарх српски бдео над тиме да дође до превазилажења раскола, али је сматрао да је то унутрашње питање СПЦ и да га не би требало решавати са било којим спољашњим факторима, без обзира на њихову добронамерност или тежњу да у томе посредују.

Ђорђе Радин упознао је Епископа Николаја 1919. године, ${ }^{21}$ и од тада је био са њим у повременом контакту. Дочекао га је 1920. и 1927. приликом његова два дужа боравка у САД.22 Према сопственом признању, био је један од организатора Владичиног доласка из Велике Британије 1946. ${ }^{23}$ Тада се поменути епископ трајно доселио у САД, где је остао до смрти. ${ }^{24} \mathrm{C}$ обзиром на то да је Радин био

${ }^{21}$ Поменуо је ово у писму Слијепчевићу 23. јануара 1967.

22 За сада није могуће утврдити стварну Радинову улогу у томе, колико је он био пресудан за те две посете, која је тачно била његова улога и задужење, и тако даље.

23 Радиново писмо упућено бискупу Епископалне цркве у Њујорку, Вилијаму Манингу (William T. Manning), 22. децембра 1945. Архива Епископалне цркве (Episcopal Church), Њујорк, William T. Manning Papers, Serbian Correspodence. Радинову тврдњу о учешћу у припреми доласка архијереја Николаја није могуће проверити у доступним архивским изворима и утврдити степен његове улоге у свему томе.

24 Допутовао је бродом „Краљица Елизабета“ (“Queen Elizabeth”), из Саутемптона (Southampton) у Енглеској, записан као путник у транзиту под редним бројем 27, Југословен по националности, пристигао из Дахауа 
вишегодишњи познавалац и пријатељ са поменутим архијерејем, а касније и његов сарадник, у раду су истакнути његови осврти на поједине секвенце из живота и рада овог значајног епископа. Прибележени су биографски подаци који нису детаљније познати, посебно о првим месецима и годинама живота и рада Владике Николаја у Америци. И поред свега наведеног, требало би имати резерве према свим запажањима и подацима које је Радин изрекао Слијепчевићу, иако су његова добра воља и труд према СПЦ и Епископу Николају неоспорни. За сада није изводљиво детаљније реконструисање првих неколико месеци, па чак и година, живота и рада архијереја Николаја у Америци ${ }^{25}$ с обзиром на несређеност и недоступност тамошњих архива. ${ }^{26}$ Ова запањујућа чињеница указује на то да су бројне личности и догађаји из тог времена или заборављени, или (неправедно) запостављени, или су табу тема, или се о њима непроверено (а самим тим и необјективно и једнострано) пише. ${ }^{27}$

У садржају рада је неколико делова одабраних писама из дописивања Радина са Слијепчевићем, и коментара на њих. Кроз поменута сведочанства осветљавају се и комплексни догађаји при СПЦ у дијаспори. Поједини моменти су непознати и нема их у ретким биографским подацима Владике Николаја.

у Немачкој. Списак путника (List or Manifest of alien Passengers for The United States of America), стр. 6, датиран 9. јануара 1946, добијен је посредством Владике западно-америчког др Максима Васиљевића.

${ }^{25}$ Срећко Петровић, „Пар узгредних напомена о проучавању наслеђа Владике Николаја Велимировића: неки истраживачки проблеми“, Теолошки йоїлеgu LIII, № 3 (2020): 828 .

26 У супротном, могло би се тачно утврдити ко се из СПЦ, на који начин и у коликој мери, потрудио и ангажовао у вези са Велимировићевим боравком и служењем у САД.

${ }^{27}$ Један од вредних изузетака је: Кринка Видаковић Петров, „Српска књижевност у дијаспори: Емилијан Божетић Глоцар“, Срйска книжевносит и евройска књижевности (Београд: Филолошки факултет, Међународни славистички центар, 2011), 2, 445-455. 


\section{Прилози: исечци из преписке Радин-Слијепчевић}

1. Радиново писмо Владици др Фирмилијану Оцокољићу 7. јула 1966.

Када ми се 1945 године Епископ Николај јавио из Енглеске са питањем да ли да дође у Америку, појавила се нова нада за Србе. Одмах сам отишао у New York и после разговора са меродавним личностима Савета Протестантских Цркава, одговорио сам нашем драгом владици: да би свакако било добро да дође у Америку на начин како је обавио посете 1921 и 1927 године, као гост Американаца. То би га омогућило да његове беседе у Протестантским црквама и говори на универзитетима, укључујући и посете српским црквама, буду у тесној сарадњи са његовим америчким сарадницима и домаћинима широм Америке. У тој црквенопросветној мисији нашег великог проповедника и просветитеља гледао сам можда последњу наду за спас Срба, јер тада Америка још није била признала безбожнички-комунистички тоталитарни режим у Београду. Уједно сам известио владику да је позван да буде гост у кући председника Union Theological Seminary у New Yorku, Dr. Henry Van Dusen-a. Владика је стигао 9 јануара 1946 око девет сати увече. Први му је пришао г. Никола Степановић, са киме се задржао у дужем разговору. Кад сам се доцније ја поздравио са владиком он ме је замолио да телефонирам Dr Van Dusenu да, као српски владика, прво треба да оде у српску цркву да се помоли Богу - да се тамо види са владикама Дионисијем и Иринејом који га тамо очекују. Одмах сам телефонирао Dr Van Dusenu, који је одговорио да подпуно разуме жељу владике и ако га не види то вече радоваће се да га поздрави ујутру при доручку. Када сам око 11 P. М. дошао по владику да га отпратим до куће Dr Van Dusena рекао ми је да ће преноћити у кући српске цркве и да дођем по њега сутрадан после подне када се тамо при- 
ређује велики пријем у његову част. Када смо идућег дана полазили запитао сам епископа где му је багаж? На ово је Епископ Дионисије одговорио повишеним гласом: „Ко је Вас одредио за managera Епископа Николаја? За њега је овде спремљен стан. Немојте се ништа бринути. Сви ће Американци трчати за нашег другог Светог Саву“. Чувши ово, погледао сам владику Николаја и рекао: „Дај Боже, али не верујем“. Било ми је јасно да су Дионисије и његова околина упропастили план о сарадњи Епископа Николаја са америчким црквама, као и могућност коју је имао 1921 и 1927 године да га вашингтонски епископ отпрати у Белу Кућу у посету Председнику Сједињених Држава Америке. После једно две недеље дана Владика Николај ме је замолио да питам Dr. Van Dusena да ли би могао да се пресели код њега, као што је раније био позват? Телефонирао сам Dr Van Dusenu. Секретарица ми је рекла да ће нам телефонирати одговор Dr. Van Dusena. Нажалост жељени одговор није дошао. Реализирајући грешку која је учињена неприхваћањем плана о сарадњи, мученик Николај повукао се у један руски манастир и умро са неисказаним болом што није могао да послужи своме народу и Цркви у времену њиховог највећег страдања.

2. Радиново писмо Слијепчевићу 5. јануара 1967.

Када сам ушао у наш дом (баш у очи званичног Божића), много хитних ствари су овде чекале - а међ најхитнијима беше молба Фирмилијана да се заузмем за дозволу за сталан боравак у Америци Проте Димитрије Најдановића (који ме је изгрдио пре 35 година када сам говорио групи Хришћанске Заједнице Младих Људи и подвукао сам да је Исус Христос био pragmatical person у својој мисији на земљи. Вођа те групе, Најдановић, кога нисам видео пре ни после тог састанка, ужасно се наљутио што сам користио прилику да проповедам „амерички прагматизам до те мере 
да чак и Сина Божјег обележим са том америчком философијом“. Кад је, после извесног времена, Николај чуо шта се десило, замерио је Најдановићу и додао: „Зар није Исус створио цркву на земљи. Може ли се замислити већи и значајнији прагматизам од тога?").

3. Радиново писмо Патријарху српском Герману 27. априла 1967.

Божији благослов довео ме је у лични контакт између првог и другог рата са сваким поглаваром наше Светосавске Цркве. Захвалан сам што ми се указује прилика да и са Вама дођем у додир бар путем писма. [...] А сад желим да Вашој Светости и осталим члановима Светог Архијерејског Сабора скренем пажњу на следећа моја искуства у погледу Срба у Америци, како пре тако и после другог светског рата: Приликом путовања са покојним Епископом Николајем широм Америке 1921 и 1927 године, упознао сам се са званичним статистикама криминалитета у Америци у сваком месту где је наш драги владика проповедао и држао предавања. Са великом радошћу преносим Вам резултат тих испитивања: Ниједно кривично дело о којима се води рачуна није теретило Србина. [...] Кад је наш Николај био у Вашингтону пре рата, оба пута одвео га је епископ ове Епископалске диоцезе у посету Председнику Cједињених Држава.

[Напомена аутора рада: Радин је прерадио писмо и 6. маја исте године спремио га је за слање поглавару СПЦ. Измењени текст, при крају писма, гласи]:

Пре неколико дана у разговору са вашингтонским епископалским епископом рекао ми је да би добро било да наш Патријарх дође у посету овде кад се смире ови трагични догађаји међ Србима у Америци. ${ }^{28}$ Владика ће бити срећан

${ }^{28}$ Односи се на раскол. 
да Вас угости на земљишту где се налази и Катедрала. Кад је наш Владика Николај био у Вашингтону пре рата, становао је на истом месту и оба пута епископ вашингтонске епископалске диоцезе одвео га је у посету председнику Cједињених Држава.

4. Радиново писмо Слијепчевићу 1. децембра 1969.

Од јуна 1919 године, када сам упознао Николаја, па до своје смрти говорио ми је своју велику тугу. Питао се зашто су Срби жртвовали чак и своје име, и целу своју прошлост, да би ступили у брак са католицима. ${ }^{29}$ Некада сам желео мислити да претерује. Сад, пак, донело ми је ово Ваше писмо и последњу вест: да су Срби аман све изгубили у томе пакленом браку.

5. Радиново писмо Слијепчевићу 14. фебруара 1970.

У недељу, 8 о. м., телефонирао ми је Фирмилијан из хотела где је одсео око 9 сати изјутра. Одмах сам му рекао да ћу их видети у цркви мало касније, али најбоље да се поразговарамо преко телефона јер ће у цркви бити више света. Он мисли да измирење неможе доћи док имовински спорови трају по судовима, што значи (он мисли) најмање још десет година. Кривицу за све то приписује адвокату бившег Дионисија, Steve Stepanovic. Одговорио сам да се у томе не могу слагати, и ако је Степановић у заједници са сотоном у мантији Дионисија успео да елиминише Николаја у

\footnotetext{
${ }^{29}$ Мисли се на стварање Југославије. Ипак, не би требало пренебрегнути да је Владика Николај то говорио у својим позним годинама, што је и Радин истакао. Међутим, у годинама пред Први светски рат, па и до 1918. године, исти тај Епископ Николај веома позитивно се изражавао о стварању заједничке државе, чак и са извесним одушевљењем, у написима и на српском и на енглеском језику.
} 
року од 24 сати пошто је стигао у New Yorku 9 јануара 1946. Појавио се на пристаништу лађе QUEEN ELIZABETH у униформи америчког мајора коју је носио за време рата када су о њему Срби говорили да служи у тајном оделењу америчке војске. Агресивно, био је први да поздрави владику. Предао му неки листић (вероватно од Дионисија) и говорио је авитаминозном заробљенику из Dachau-a 10 до 15 минута. Онда је одјурио поред мене као поред неког зликовца, и после пола сата видео сам га поред Дионисија у српској цркви у New Yorku где сам одвео Николаја од пристаништа лађе. Моје прве речи на пристаништу лађе Николају беше: „Драги наш владико. Ви сте авитаминозан после Dachau-a и још више после Лондона. Међутим Ви сте стављени у положај да, у таквом Вашем физичком стању, донесете највећу одлуку, најсудбоноснију по српски народ у времену у којем живимо: Хоћете ли се држати плана утврђеног у коресподенцији са мном из Лондона да будете у Америци гост Американаца и да, разуме се, посећујете и Србе широм Америке где будете држали беседе у црквама и говоре на универзитетима (као што то беше приликом двеју Ваших посета овде када сам Вас пратио), или ћете пристати да будете гост Срба овде и да покушавате да посећујете и Американце докле будете остали у овој земљи. Овај мајор који Вас је поздравио, иначе адвокат Дионисија, са Дионисијем и другим Србима из New Yorka спремили су Вам стан близу српске цркве; а, као што сам Вас известио председник Union Theological Seminary на Columbia University, Dr. Van Dusen, спремио је стан за Вас у великој кући Семинара где станује, у договору са познатим Американцима који су ушли у Комитет са задатком да се брину у погледу Ваших беседа широм Америке у Протестантским црквама и по универзитетима. У плану је да Bac Bishop Dan у Вашингтону одведе Председнику Труману, као што су Bac Bishop Donovi предходници водили у Белу Кућу приликом ранијих Ваших посета. А ја ту осећам Божију милост јер Америка још није признала убице Срба 
које им је Ваш сапутник из Лондона (Churchill) уз помоћ зликовца Стаљина силом наместио да владају и над Србима који су преживели покољ“.

6. Слијепчевићев одговор Радину 21. фебруара 1970.

Да, заиста, судбина покојнога владике Николаја тамо била је тешка. Ја сам био уз њега од 24.IV.1945 па све до августа те исте године и знам добро шта је он осећао и преживљавао у то време. Ја сам му, тада, био оно што се зове „момак“, пазио сам на њега и послуживао га у свему. Он ме је повео са собом када су он и патријарх Гаврило били „пошли“ у Швајцарску, а у ствари су били заведени за Голеш планину: где сутри дан после подне смо схватили где смо на станици Malnitz у Аустрији и пред вече смо доведени у Kitzbüchel, где је био и пок. генерал Недић. Знам и за њихове муке да им се дозволи одлазак у Швајцарску на лечење и за осећање унижења када им се није одговарало на писма. И за буквално гладовање и примање хране са немачког избегличкога казана са кога сам ја за нас доносио храну: неку врсту чорбе са водом и нешто поврћа... Све су то били тешки дани, али му је, верујем, и то било лакше од понижавања која је доживљавао од Дионисија тамо.

7. Приватно писмо Патријарха српског Германа Радину 7. јуна $1971 .^{30}$

Врлопоштовани и драги г. Радин, Хвала на писму послатом по Преосвећеном Фирмилијану. Хвала и на добрим намерама и залагању да се поврати јединство Српске Православне Цркве. То и ми желимо и за то се свакодневно

\footnotetext{
${ }^{30}$ На бројне Радинове захтеве да се хришћани других конфесија, посебно протестанти, укључе у посредовање ради измирења СПЦ са расколницима уследио је одговор првопрестолника СПЦ.
} 
Богу молимо. Ми смо о томе проблему овде потанко разговарали и свестрано претресли са Преосвећеним Фирмилијаном и свима Архијерејима Српске Цркве. Сви бисмо желели да дође до мира и пуног јединства у Цркви. Највећа срећа би нам била да се сви наши Срби поврате у крило Мајке Цркве. О томе се може и треба увек разговарати и пут тражити. Чини нам се само да би било боље да тај наш „домаћи“-унутрашњи проблем наше Цркве расправљамо и решавамо сами без мешања иноверних, па ма они били и наши велики пријатељи. Ја Вас молим да Вашу идеју о томе не напуштате већ да о њој и даље са Преосвећеним Фирмилијаном разговарате и потражите заједнички најбољи пут и најбоље решење. Он је сада још више и још боље упућен у читаву ту проблематику. Желећи Вам свако добро од Бога срдачно Вас поздравља и шаље благослов. Патријарх српски, Герман.

\section{Закључак}

Ставови Ђорђа Радина истакнути у преписци са Слијепчевићем указују на специфично сагледавање личности и животних околности Владике Николаја у последњој деценији његовог живота, кроз перо једног исељеника који је направио успешну каријеру у САД, а који је са поменутим архијерејем имао лични однос. Осим поменутог и прокоментарисаног у самим писмима, занимљиво је и оно што су Радин и Слијепчевић један другом прећутали. Радин није поменуо да је имао везе у врху власти, али и међу разним политичким групама и међу утицајним појединцима у међуратном периоду у Југославији. Такође, вешто је избегао и било какво указивање на свој обавештајни рад или на своју улогу у пучу 27. марта 1941, о чему се понешто може сазнати тек у последње време, и то у ретким архивима, од којих је већина, још увек, не- 
доступна истраживачима. С друге стране, Слијепчевић је ускратио Радину податак о разлазу са Епископом Николајем, управо у периоду који је поменуо у једном од допиca, а који се налази у прилогу рада. Из Слијепчевићевог архива може се сазнати да је он Владици Николају послао барем једно писмо после прекида њихове сарадње, а јасно је и да је Епископ Николај најмање једном писао или одговорио Слијепчевићу. До сада није пронађен ниједан допис Велимировић-Слијепчевић из кога би се сазнало нешто више.

Уз несумњиви однос међусобног поштовања и уважавања Радина и Слијепчевића, може се закључити и да су, на известан начин, један другом били потребни. Радин је Слијепчевићу био од користи ради лакшег путовања у САД и добијања визе за одласке у Америку, а Слијепчевић Радину због лакшег приступа појединим епископима, па и поглавару СПЦ, а највероватније и ради сазнавања одређених информација, било о политичким емигрантима, било о активностима збораша у Минхену, а напослетку и обавештавања о трвењима и сукобима Срба у вези са расколом при СПЦ у САД.

Иако је Радин само један од сведока тешког и нехармоничног десетогодишњег живота и рада Владике Николаја на америчком континенту у послератном периоду, фрагменти писама су значајни јер указују на многе несрећне и болне теме, које су ретко помињу и које су остале недоречене, непротумачене, чак ни фактографски приказане и побројане, док о критичком сагледавању нема ни говора. Стога Радинова запажања представљају један мали прозор кроз који се може завирити у компликовано и суморно стање међу српским исељеницима у Америци, којима су се по престанку Другог светског рата придружили бројни политички емигранти.

Радинови коментари о расколу нису били опширни, па ни Слијепчевић ништа ново, важно или поверљиво није сазнао од њега о том питању. Ипак, оно што је вредно јесте 
јасан увид, који произилази из писама која су у исечцима цитирана у раду, у то да су се двојица не тако познатих Срба потрудили да утичу да дође до прекида раскола. Иако је неки значајан или велики резултат изостао - јер је раскол трајао скоро три деценије, и оставио је (страшне) последице које су присутне и у данашњем времену - из дописа се сазнаје да су постојали поједини Срби, ретки верници, који су се кретали ка тражењу пута и прихватљивог начина да се дође до измирења у Цркви.

Премда Радиново помињање Епископа Николаја нема никакве везе са расколом, који је започет 1963, односно неколико година после смрти архијереја Николаја 1956, ипак је јасно да је Владика Дионисије био на „клизавом путу“ дуго времена. Радин јесте добро проценио да ће истинска сарадња изостати, да ће она унети проблеме, као и да ће бити пропуштена велика и немерљиво важна прилика да Епископ Николај учествује у верском животу и раду Срба, односно да има ангажман какав му доликује, најпре при епархији СПЦ у Америци. С обзиром на ретке радове о тој теми, из којих би се могло закључити нешто више и одређеније о односу највиших црквених великодостојника СПЦ у САД у послератном периоду, није лако проценити да ли је Радин био у праву, и у коликој мери. Такође, он је многе записе исказао post factum, па је и питање да ли је у потпуности био објективан, или више сетан и емотиван, чак и разочаран. Његови коментари су значајни јер указују на изостанак било какве повезаности Епископа Николаја и Епископа Дионисија, упркос свим њиховим различитим погледима на црквено, национално, идеолошко или било које друго питање или уређење, па чак и однос према прошлости.

Када је у питању раскол при СПЦ у САД, из писама се види и Радинова потреба да се једног момента прибегне необичном моделу: да се затражи помоћ за решавање тешког и (тада) несагледивог спора у СПЦ са инославнима, односно протестантским заједницама. Иако је, неоспорно, 
Радин имао углед у тим верским заједницама, Патријарх српски Герман одлучио је да му личним писмом укаже да то није црквени начин и да то није пут којим се црквени проблеми решавају и превазилазе.

Сагледавање дела преписке Радин-Слијепчевић која се тиче Епископа Николаја и раскола при СПЦ има значај јер се њоме даје глас онима који су на свој начин тежили поништавању расцепа и превазилажењу подела, а претходно исказали одређену бригу о значајном српском владици, који је и у данашњем времену предмет разних тема, различитих тумачења, а неретко је и оспораван и критикован. Управо су фрагменти писама корисни као мали део слагалице, за једно објективније и неоптерећено приказивање и вредновање и Владике Николаја, и раскола при СПЦ у Америци, и то кроз мисли Радина и Слијепчевића, који су о поменутом изрекли понешто у времену самих дешавања, или непосредно после њих.

$* * *$

\section{Резиме}

Један од бројних српских исељеника у Америку у периоду пред Први светски рат био је и Ђорђе Радин. Он се школовао при престижним америчким училиштима. Постао је правник, адвокат и стручњак за међународно право. Успео је да достигне висок ниво на лествици спољне политике и дипломатије САД.

У међуратном периоду упознао је Владику др Николаја Велимировића, који је на њега оставио снажан утисак. Био му је један од водича по Америци, два пута: 1920. и 1927. године. Током прве посете поменути епископ организовао је живот СПЦ на том континенту, с обзиром 
на то да није било сталног надлежног епископа поменуте верске заједнице.

Радин је, према сопственој тврдњи, био један од организатора доласка Епископа Николаја у Америку почетком 1946. године. Он је сматрао да би овај значајни архијереј требало да живи при некој од протестантских цркава, држи предавања на универзитетима, и на тај начин служи СПЦ и њеним верницима. Односно, био је убеђен у то да би Владика Николај требало да организује живот на начин како је то чинио у претходне две посете САД. Међутим, ситуација у послератном периоду била је много комплекснија. Српска Црква имала је на поменутом простору надлежног Владику америчко-канадског Дионисија Миливојевића, који се врло брзо по досељењу архијереја Николаја у САД разишао са њим. Непроцењива је штета што није постојала ни најмања сарадња између ове двојице епископа. Владика Николај пронашао је „соломонско решење“ и одлучио је да живи и ради у манастиру Светог Тихона у Саут Канану (South Canaan), у Пенсилванији. ${ }^{31}$ У тој светињи се и упокојио 1956. године.

Радин је до краја живота сматрао да је суштинска грешка била у извесном прекиду могућности да кроз боравак при протестантским заједницама Епископ Николај уради више за СПЦ и Србе, посебно кроз познанства и контакте са представницима других хришћанских конфесија, a најпре са протестантима. Он је то помињао у преписци са Слијепчевићем. Такође, Радин је покушавао и да утиче на све начине да дође до прекида раскола. Он је писао о својим замислима владикама СПЦ, као и самом поглавару. Обавештавао је Патријарха српског Германа Ђорића о својим идејама и предузетим корацима у том смеру. Иако

\footnotetext{
31 Тадашња Митрополија северноамеричка, којој је припадала поменута обитељ, касније се прогласила за Америчку Православну Цркву (Orthodox Church of America). Руска Православна Црква доделила јој је аутокефалност 1970. године, али ту аутокефалност нису потврдиле све православне помесне цркве.
} 
је првопрестолник СПЦ покушавао да се дође до прекида црквеног расцепа, он је једног момента поучио Радина о томе да је то претешко и несрећно питање унутрашња ствар Српске цркве, и да је не би требало решавати ван ње.

У прилогу рада налазе се исечци седам писама, пронађених у преписци Радин-Слијепчевић. Из њих се види велико поверење и међусобно уважавање послератних познаника, који су се упознали вољом архијереја Николаја. У њима провејавају ставови угледног правника и адвоката Радина, који је на свој начин покушавао да ради у корист СПЦ. Такође, приметни су његови осврти о значају Владике Николаја, као и његов суд о пропуштеној прилици да поменути епископ много више уради за Цркву, њене вернике и све Србе, и на америчком континенту, и у целом свету. Јасно је да је он у томе остао спутан, између осталог и вољом Владике Дионисија. Само неколико година после смрти Епископа Николаја, започео је најкомплекснији проблем СПЦ у дијаспори - раскол. Своју пажњу и велики труд, Радин је усмерио ка превазилажењу тог искушења, на начин који је сматрао најприхватљивијим. Он је у свему томе имао разумевање и подршку Слијепчевића, са којим је одмеравао најбољи начин да се дође до измирења. Фрагменти писама упућују да је свој исељенички живот добрим делом посветио бризи о архијереју Николају и борби против раскола и могућности његовог превазилажења. 


\section{Библиографија}

\section{Необјављени архивски извори}

Преписка Ђорђа Радина и Ђока Слијепчевића, Лични фонд Немање Андријашевића, Минхен, Савезна Република Немачка.

Писмо Ђорђа Радина упућено бискупу Епископалне цркве у Њујорку Вилијаму Манингу 22. децембра 1945, Архива Епископалне цркве (Episcopal Church), William T. Manning Papers, Serbian Correspodence, Њујорк.

Списак путника (List or Manifest of alien Passengers for The United States of America), датиран 9. јануара 1946, добијен посредством Владике западно-америчког др Максима Васиљевића.

\section{Објављени архивски извори}

Велимировић, Николај. Сабрана gела, ХІІІ. Шабац: Манастир Светог Николаја Соко, 2016.

\section{Штампа}

Бисенић, Драган. „Осам деценија чувана тајна скриваног писма које је променило историју Југославије. Улога Ђорђа Радина у државном удару 27. марта 1941.“ НИН № 3665 (25. март 2021): 6-13.

\section{Литература}

Велимировић, Николај. Сабрана gела, 1-12. ДиселдорфХимелстир: Српска Православна Црква, Епархија западноевропска, 1976-1986. 
Видаковић Петров, Кринка. „Српска књижевност у дијаспори: Емилијан Божетић Глоцар“. Срйска книжевности и евройска књижевности, 2, 445-455. Београд: Филолошки факултет, Међународни славистички центар, 2011.

Петровић, Срећко. „Пар узгредних напомена о проучавању наслеђа Владике Николаја Велимировића: неки истраживачки проблеми“. Теолошки йоїлеgи LIII, № 3 (2020): 827-832. https://doi.org/10.46825/tv/2020-3-827-832.

Слијепчевић, Ђоко. Оірешења влаgике Дионисија. Минхен: самостално издање писца, 1963.

Слијепчевић, Ђоко. Исииорија Срӣске Православне Цркве, 1-3. Београд: Catena mundi, 2019.

Спасовић, Станимир. Истиорија Срӣске Православне Цркве у Америци и Канаgи оg 1941. gо 1991. іоgине. Торонто: Источник, 1997.

Шмеман, Александар. Наш животи у Христиу, Христиов животи у нама: изабране бесеgе, есеји, сйуgије и ояломии из Дневника 1973-1983. Превео и приредио Матеј Арсенијевић. Библиотека „Образ светачки“, књ. 28. Београд: Мисионарска школа при Храму Светог Александра Невског, 2007. 